\title{
Research Progress in Magnesium Alloys as Functional Materials
}

\author{
Chen Xianhua ${ }^{1,2}$, Geng Yuxiao', Pan Fusheng ${ }^{2,3}$ \\ ${ }^{1}$ Chongqing University, Chongqing 400045, China; ${ }^{2}$ National Engineering Research Center for Magnesium Alloys, Chongqing 400045, \\ China; ${ }^{3}$ Chongqing Academy of Science and Technology, Chongqing 401123, China
}

\begin{abstract}
Magnesium alloys have a significant advantage, low density over other structure metals currently and have been widely used in various fields such as transportation and aerospace. With the development of research and the enlargement of research scope, more advantages have been developed: high storage capacity, high theoretical volumetric energy density, extraordinarily high damping capacity, good biocompatibility, excellent shielding efficiency as well as impressive thermal conductivity. Therefore $\mathrm{Mg}$ alloys have the potential to be various functional materials, such as hydrogen storage material, rechargeable electrochemical batteries, damping material, biodegradable implant material, electromagnetic shielding material, and thermal conductive material. Unfortunately, each kind of functional material has bottlenecks needing to be broken through, and a lot of researches have to be carried out. This review comprehensively covers the research progress and the up-to-date summary of $\mathrm{Mg}$ and $\mathrm{Mg}$ alloys as functional materials in recent years. The six kinds of functional materials above all will be discussed.
\end{abstract}

Key words: magnesium alloys; functional materials; novel processing; properties; alloying

Magnesium alloys are getting speedy development in recent years because of their inherent advantages such as low density and high specific strength ${ }^{[1]}$. With the development of researches, numerous appealing properties of $\mathrm{Mg}$ and its alloys are found and they are considered to be the promising candidates for functional materials in various applications because of the special advantages compared to other alloys ${ }^{[1-5]}$ For example, $\mathrm{Mg}$ alloys have high storage capacity, so their hydrides are promising to be hydrogen carriers. Pure $\mathrm{Mg}$, $\mathrm{Mg}-\mathrm{Ni}, \mathrm{Mg}-\mathrm{Al}$, and $\mathrm{Mg}-\mathrm{Re}$ etc. have been developed as $\mathrm{Mg}$ hydrogen storage materials. In addition, $\mathrm{Mg}$ is expected to be an alternative to lithium in the future ion-transfer batteries duo to its higher safety and lower cost. $\mathrm{Mg}-M-\mathrm{B}(M=\mathrm{Co}, \mathrm{Ni}$, $\mathrm{Fe}, \cdots \cdots)$ and $\mathrm{Mg}-M-\mathrm{SiO}_{4}(M=\mathrm{Mn}, \mathrm{Fe}, \mathrm{Co})$ were investigated as positive electrode materials for magnesium batteries. $\mathrm{Mg}$ alloys' damping capacity is excellent, so they can be used in anti-vibration and noise-reduction applications. $\mathrm{Mg}$ alloys also exhibit good biocompatibility and are ideal implant materials because the content of magnesium in cells is the second largest, and the mechanical properties are close to those of natural bone. $\mathrm{Mg}-\mathrm{Ca}$ and $\mathrm{Mg}-\mathrm{Sr}$ series alloys coated by calcium phosphate or hydroxyapatite (HA) exhibit appropriate corrosion rate and good biocompatibility, and reach the requirement of an ideal implant material. What's more, $\mathrm{Mg}$ alloys are prominent candidate materials to reduce the harm of electromagnetic wave because of their high electromagnetic shielding performance. And the good thermal conductivity makes them have the potential to be radiator materials. However, there are still many problems to be solved for implementing functional $\mathrm{Mg}$ alloys widely. Considerable researches have focused on specific functional properties of $\mathrm{Mg}$ alloys and some alloy series have been investigated in particular areas. The present paper will focus on the research progress of magnesium alloys in these aspects, and the research hotspots and the development tendency of further research is summarized in detail. Such a review can provide

Received date: September 19,2015

Foundation item: International Science \& Technology Cooperation Program of China (2014DFG52810); National Natural Science Foundation of China (51571043); Fundamental Research Funds for the Central Universities (106112015CDJZR135515)

Corresponding author: Chen Xianhua, Ph. D., Professor, College of Materials Science and Engineering, Chongqing University, Chongqing 400045, P. R. China, Tel: 0086-23-65102633, E-mail: xhchen@cqu.edu.cn 
important information for further development of $\mathrm{Mg}$ alloys as functional materials.

\section{Hydrogen Storage Materials}

Hydrogen gas will be the most promising fuel in the future because it is the most abundant resource and green in energy. Hydrogen can be stored as pressurized gas, cryogenic liquid, and solid state hydrogen. Solid-state storage is more economic and safer than gas and liquid storage methods, and many efforts have been made to research solid materials. The US Department of Energy (DOE) proposed a target: the optimal desorption temperature ranges from 60 to $120{ }^{\circ} \mathrm{C}$ as well as the hydrogen storage capacity is $6.5 \mathrm{wt} \%$ at least ${ }^{[6,7]}$.

$\mathrm{Mg}$ is a promising candidate for hydrogen storage in various applications due to its light weight, high storage capacity, reversibility and recyclability. $\mathrm{Mg}$ alloys combine chemically with hydrogen to form hydrides that are known as $\mathrm{Mg}$ hydrogen-storage materials. In the past decade, a series of hydrides have been prepared, such as $\mathrm{Mg}_{2} \mathrm{NiH}_{4}, \mathrm{Mg}_{2} \mathrm{FeH}_{6}, \mathrm{Mg}$ $\left(\mathrm{AlH}_{4}\right)_{2}$ and some unusual metal hydride $\mathrm{Mg}_{2} \mathrm{CoH}_{5}, \mathrm{Mg}_{3} \mathrm{ReH}_{7}$, $\mathrm{Mg}_{3} \mathrm{CrH}_{6}$. However, $\mathrm{Mg}$ alloy hydrides are still far from meeting the need for practical applications because of high hydrogen discharge temperature, complicated synthesis process, slow desorption kinetics and high reactivity toward air and oxygen ${ }^{[7-9]}$.

Corresponding to the challenges in application, lots of researches have been carried out to find viable solutions to optimize hydrogenation properties. The commercial hydrogen storage and utilization can be achieved by decreasing the temperature of hydrogen desorption, enhancing the kinetics and improving the cycle life span. Alloying and microstructure modification are the main approaches to improve the hydriding properties ${ }^{[10-12]}$. Shao et al reported that $\mathrm{Mg}$-Co alloys present high hydrogen storage capacity of around $3 \mathrm{wt} \%^{[10]}$, which is obviously higher than that of $\mathrm{TiFe}_{0.86} \mathrm{Mn}_{0.1-x} \mathrm{Co}_{x}$ alloys (1.98 $\mathrm{wt} \%)^{[13]}$. It was found that the hydrogenation kinetics and the $\mathrm{H}$-storage capacity are dependent on the microstructure and phase composition of the alloys. Large grain boundary area as well as small particle sizes are beneficial to decrease the desorption energy and to reduce the desorption temperature ${ }^{[14-16]}$. Ballmilling is a main synthesis technique and widely applied to produce hydrogen storage materials. A large amount of fresh surface and defects produced during milling process are contributed to the kinetics enhancement. The nanostru- ctured composites alloying with other transition metals and their oxides can also reduce the desorption temperature and improve the thermodynamic. However, nano-sized $\mathrm{Mg}$ is sensitive to oxygen, which is very dangerous and difficult to store and deliver ${ }^{[14-16]}$. A core-shell structured $\mathrm{Mg}$ based nano-composite is an ideal solution to protect the surface of nano-sized $\mathrm{Mg}$ for the sake of safety ${ }^{[10,11]}$. J. X. Zou et al. developed a core-shell structured $\mathrm{Mg}$ based nano-composite with the surface of $\mathrm{Mg}$ particles covered by $\mathrm{MgO}, \mathrm{RE}_{2} \mathrm{O}_{3}$ nano-grains, which significantly improved hydrogen storage thermodynamic, kinetic and anti-oxidation properties ${ }^{[6]}$.

The absorption/desorption kinetics can also be improved by adding catalyst. It was known that some metals and transition metal oxides (such as $\mathrm{Al}, \mathrm{Fe}, \mathrm{Ti}, \mathrm{B}, \mathrm{Zr}, \mathrm{Nd}_{2} \mathrm{O}_{5}$ and $\mathrm{V}_{2} \mathrm{O}_{5}$ ) could be efficient additives. For example, $\mathrm{Mg}_{2-x} \mathrm{Al}_{x} \mathrm{Ni}(x \leqslant 0.1)$ has lower desorption temperature and faster desorption rate than Mg-Ni. Adding $\mathrm{Nb}_{2} \mathrm{O}_{5}$ especially nanocrystalline $\mathrm{Nb}_{2} \mathrm{O}_{5}$ in $\mathrm{MgH}_{2}$ improves desorption capacity and cyclic stability significantly ${ }^{[16-18]}$.

\section{Rechargeable Magnesium Batteries}

Lithium ion batteries play an important role in the field of portable electronic devices, electric vehicles (EV) and other energy storage systems. However, the safety and high cost are the main disadvantages that have not been resolved, since the electrolyte is easy to burn and $\mathrm{Li}$ is expensive $[19,20]$. Consequently finding new types of batteries with greater safety and lower cost is urgent. The theoretical volumetric energy density of Mg-ion batteries is $3832 \mathrm{mAh} \cdot \mathrm{cm}^{-3}$ higher than that of $\mathrm{Li}\left(2061 \mathrm{mAh} \cdot \mathrm{cm}^{-3}\right)$, and $\mathrm{Mg}$ is relatively cheaper and safer than $\mathrm{Li}$. $\mathrm{Mg}$ is expected to be an alternative to lithium in the future ion-transfer batteries. Since Aurbach et al. made a complete $\mathrm{Mg}$ rechargeable battery in 2000, more and more research institutions turned their sight to magnesium batteries ${ }^{[19-23]}$.

Suitable electrodes for magnesium ion insertion, de-insertion and conducting electrolytes are critically important for $\mathrm{Mg}$ rechargeable batteries. While the $\mathrm{Mg}$-ion is difficult to diffuse in solid-state electrode compared to the Li-ion, and the corrosion resistance of the magnesium battery is low. The reactions of the anode with electrolyte would produce a blocking layer, which limits the achievable battery voltage and leads to the poor cycling ability of $\mathrm{Mg}$ batteries. For Mg batteries, the choice of electrolyte is also very critical. There are two aims in present research activities: one is to find suitable cathodes for magnesium ion insertion and de-insertion or commercially viable active materials for $\mathrm{Mg}$-ion batteries; the other is to prepare suitable magnesium ion conducting electrolytes with sufficiently ionic conductivity ${ }^{[23-25]}$.

Although a lot of researches have been carried out, the development of magnesium batteries is still at a preliminary stage, and their poor catalytic activity and low corrosion resistance still restrict their practical applications. The initial research activities focused on various potentially promising metal oxides (vanadium and molybdenum oxides), sulfides and other insertion compounds in organic solvents and low-temperature salt melts; then manganese dioxide $\left(\mathrm{MnO}_{2}\right)$ and its polymorphs, $\mathrm{Mg}-M-\mathrm{B} \quad(M=\mathrm{Co}, \mathrm{Ni}, \mathrm{Fe}, \cdots \cdots)$, $\mathrm{Mg}-\mathrm{M}-\mathrm{SiO}_{4}(M=\mathrm{Mn}, \mathrm{Fe}, \mathrm{Co})$ were investigated as a positive electrode material for magnesium batteries ${ }^{[23]}$. Nevertheless, there is no $\mathrm{Mg}$ battery system that is comparable to the Li-ion battery in the overall performance at present ${ }^{[26,27]}$. It was 
reported that micrometer-sized electrode with a mesoporous structure had faster kinetics as well as better morphological stability, because the mesoporous structure could act as a buffer layer and the damage caused by volume expansion during the cycling process was alleviated. $\mathrm{MgCoSiO}_{4}$ with a mesoporous structure prepared by Yupei Zheng et al. showed a larger discharge capacity and a better recyclability compared with conventional bulk forms ${ }^{[28-30]}$.

Since magnesium is very active in aqueous solution, the battery is difficult to keep stable. Solid, gel-polymer as well as molten electrolytes were the promising electrolytes in $\mathrm{Mg}$ ion batteries ${ }^{[26,28,31]}$. It was reported that magnesium achieved reversible deposition in Grignard reagents, but the preparation process was complicated. In addition, Jinjie Zhu et al. demonstrated that the halogen-free electrolyte indeed lessened the corrosion to conventional metal current collectors. They prepared a new type of halogen-free boron based electrolyte $\left(\mathrm{Mg}\left[\mathrm{Mes}_{3} \mathrm{BPh}\right]_{2} / \mathrm{THF}\right)$, which possessed high ion conductivity $\left(1.5 \times 10^{-3} \mathrm{~S} \cdot \mathrm{cm}^{-1}\right)$ and good $\mathrm{Mg}$ deposition dissolution reversibility ${ }^{[19-21,29,30]}$.

\section{Damping Materials}

Materials with high damping capacity can suppress vibration, control noise and have good structural stability. Pure $\mathrm{Mg}$ and some $\mathrm{Mg}$ alloys such as $\mathrm{Mg}-\mathrm{Zr}{ }^{[32]}, \mathrm{Mg}-\mathrm{Si}^{[33]}$ and $\mathrm{Mg}-\mathrm{Ni}{ }^{[34]}$ exhibit extraordinary high damping capacity. However, $\mathrm{Mg}-\mathrm{Ni}$ alloys have poor corrosion resistance, $\mathrm{Mg}$ - $\mathrm{Zr}$ alloys are difficult to get alloying, and damping capacity of some commercial $\mathrm{Mg}$ alloys such as AZ31 and ZK60 is obviously lower than that of pure magnesium ${ }^{[35,36]}$. Several methods have been employed to enhance their properties, including heat treatment, plastic deformation and alloying ${ }^{[32,33,35,37]}$. But these developed alloys barely have both high damping capacity and good mechanical properties.

At present, the Granato-Lucke model is usually used to explain damping mechanism: the dissipation of mechanical energy is connected with the vibrations of shorter dislocation segments and the break away from weak pinning points. Therefore, the movement of internal defects is beneficial to improve damping capacity of materials, while there is no benefit to mechanical strength. The strength and damping capacity seem to be a contradiction for Mg alloys. In 2003, K. Nishiyama et al. sintered $\mathrm{Mg}-\mathrm{Cu}-\mathrm{Mn}$ alloy by powder metallurgy (PM) that showed higher damping capacity at strain amplitudes above $4 \times 10^{-5}$ as well as tensile strength (290 $\mathrm{MPa})$ than pure magnesium ${ }^{[38]}$. But the technique of power metallurgy is expensive and complicated. Efforts are still needed to balance the damping capacity and mechanical strength.

Some researches were still focused on balancing the damping properties and mechanical properties by heat treatment, alloying with other elements and plastic deformation. Alloys with favorable strength such as $\mathrm{Mg}-\mathrm{Zn}-\mathrm{Y}-\mathrm{Zr}$ and alloys with high damping capacity like $\mathrm{Mg}-\mathrm{Cu}-\mathrm{Mn}$ were the research hotspot ${ }^{[32,39-41]}$. A new damping mechanism called 'LPSO mechanism' was systematically investigated in the series alloy, because the long period stacking ordered (LPSO) structure existing in $\mathrm{Mg}-\mathrm{Zn}-\mathrm{Y}-\mathrm{Zr}$ alloys could optimize the mechanical properties as well as damping capacities simultaneously ${ }^{[42,43]}$. Adding appropriate amount of $\mathrm{Y}$ and $\mathrm{Zn}$ in $\mathrm{Mg}-\mathrm{Cu}-\mathrm{Mn}$ alloys led to the increase of mechanical properties in different degrees and had no damage to their damping performance ${ }^{[41]}$. Moreover, the equal channel angular processing (ECAP) and small tensile strain increased the damping capacity significantly at elevated temperatures ${ }^{[40]}$. Other researchers emphasized that more attention should be paid to the basic research, since a clear understanding on damping mechanism is beneficial to design high damping-high strength $\mathrm{Mg}$ alloys. They devoted themselves to the mechanism of the damping capacities of $\mathrm{Mg}$ alloys with very simple structures (such as pure $\mathrm{Mg}$ ) or with no (or very less) solute and un-solute atoms, second phases such as $\mathrm{Mg}-\mathrm{Ni}$ and $\mathrm{Mg}-\mathrm{Mn}{ }^{[35,36]}$. It was reported that the addition of $\mathrm{Mn}$ improved not only the corrosion resistance and strength, but also their damping capacity because the long dislocations were connected to the dispersed $\alpha-\mathrm{Mn}^{[36]}$. Even so, there is no breakthrough in the field of damping theory of $\mathrm{Mg}$ alloys, and further studies are still needed ${ }^{[37,41,43]}$.

\section{Biodegradable Implant Materials}

Metal implants such as titanium alloys, stainless steel and cobalt-chromium alloys have been used as tiny tubular mesh-like structures extensively. However, these materials show higher Young's modulus than bones and poor biocompatibility. So the bio-active and biodegradable implant shave received much attention ${ }^{[44,45]}$. Magnesium and its alloys have been considered to be safe as implantable materials, because magnesium is largely found in bone tissue and the mechanical properties of $\mathrm{Mg}$ are close to those of natural bone. Furthermore, $\mathrm{Mg}$ alloys are able to degrade gradually in physiological environment, avoiding the secondary operation after being implanted ${ }^{[44,45]}$. Additionally, magnesium-based materials have received considerable attention as a promising candidate for a new generation of biodegradable vascular stent materials, owing to their in vivo degradation characteristics and non-toxicity ${ }^{[46]}$. However, there are several shortcomings for $\mathrm{Mg}$ alloys as implants. Damage will be born duo to the higher corrosion rate of $\mathrm{Mg}$ in physiological environment. The hydrogen and magnesium ions generated in the corrosion process are harmful to health, and rapid corrosion is a major reason for the failure of magnesium implants ${ }^{[46,47]}$. Controlling the degradation rate of bioactive magnesium implants is the focus of all researches.

In recent years, $\mathrm{Mg}$ alloys with various chemical compositions have been evaluated on biocompatibility, strength and corrosion rate. In order to prevent the toxicity and other adverse tissue reactions, the alloying elements existing 
in human body or having beneficial effects on tissue regeneration were chosen when designing alloys ${ }^{[48-52]}$. There are some new $\mathrm{Mg}$ alloys developed for implant application, mainly including $\mathrm{Mg}-\mathrm{Ca}, \mathrm{Mg}-\mathrm{Zn}$ and $\mathrm{Mg}-\mathrm{Sr}$ alloys, because $\mathrm{Ca}$, and $\mathrm{Sr}$ are found to be essential elements for bone remodeling, metabolism and regeneration ${ }^{[53-55]}$. The proper alloy design can improve the corrosion resistance. The corrosion rate is characterized by $\mathrm{pH}$ change or the hydrogen volume released from samples during immersion testing ${ }^{[56]}$. The corrosion resistance of $\mathrm{Mg}-0.3 \mathrm{Sr}-0.3 \mathrm{Ca}$ alloy is obviously higher compared with pure $\mathrm{Mg}$.

Surface modification is considered to be an effective method to decrease the corrosion rate of magnesium alloys. For example, the bio-active and biodegradable calcium phosphate or hydroxyapatite (HA) covered on the surface of $\mathrm{Mg}$ alloys improved the corrosion properties as well as the biocompatibility $^{[47,48]}$. Micro-arc-oxidation (MAO), electrochemical deposition and magnetron sputtering were applied to form a protective layer on the alloy surface ${ }^{[49-51]}$. The volume of hydrogen evolved was much lower for the MAO-treated $\mathrm{Mg}-\mathrm{Ca}$ alloy sample than the untreated one ${ }^{[51,52]}$.

\section{Electromagnetic Shielding Materials}

The accurate, reliable and safe output is critically important for equipment, but they are suffering from unwanted electromagnetic interference (EMI) from other communication systems. Moreover, the radiation coming from devices also generates health trouble. Consequently, the development of EMI shielding materials is in urgent need in order to diminish the trouble produced by electromagnetic radiation ${ }^{[57,58]}$.

Metals (such as copper and steel) are widely used for EMI shielding due to their high shielding effectiveness of 40 100 $\mathrm{dB}$. The primary mechanism of EMI shielding is reflection because free electrons in them can be the mobile charge carriers. Metals with good electrical conductivity such as copper are all the common candidates for EMI shielding materials. Nevertheless, these metallic materials suffer from their heavy weight, which restricts their applications ${ }^{[59,60]}$. Magnesium not only possesses low density, but also has relatively good conductivity and shielding capacity. In recent years, some researches have been performed on shielding properties of $\mathrm{Mg}$ and its alloys ${ }^{[59,61]}$. Zhihua Zhang et al. compared the electromagnetic shielding effectiveness of magnesium sheets with that copper, nickel, and aluminum ${ }^{[62]}$. In the whole frequency range, the EMI effectiveness of $\mathrm{Mg}$ ranged from $60 \mathrm{~dB}$ to $75 \mathrm{~dB}$ higher than that of $\mathrm{Al}$ with the same thickness. IBM has made laptop shells with AZ91D alloy. The thickness of these shells was about $1.4 \mathrm{~mm}$ and the shielding capability was stable at 90 100 dB in the 30 200 $\mathrm{MHz}$ frequency range. Various commercial $\mathrm{Mg}$ alloys were evaluated on the strength and EMI shielding effectiveness, and methods that could improve the EMI shielding of $\mathrm{Mg}$ alloys were put forward. Xianhua Chen et al. found that the shielding effectiveness of ZK60 alloy increased gradually with the increasing of second phase precipitates, and artificial aging treatment following solid solution enhanced the shielding capacity of extruded ZK60 obviously ${ }^{[63,64]}$. The present researches on EMI shielding properties of $\mathrm{Mg}$ alloys are far from the wide application of $\mathrm{Mg}$ alloy shielding materials. The shielding mechanism of $\mathrm{Mg}$ alloys still needs to be investigated comprehensively and thoroughly.

\section{Thermal Conductive Materials}

In the field of the electronic devices and semiconductors, the thermal conductivity property is demanded highly and the thermal conductivity becomes a critical index when selecting a material. Thermal conductivity of metals is higher than others such as composite materials and polymer materials. However the heavy weight of some metals restricts their application in portable electronic devices. $\mathrm{Mg}$ is an exception: the thermal conductivity of $\mathrm{Mg}$ alloys is better than that of the resin and plastic products; besides their light weight makes them more suitable in the field of electronic packaging ${ }^{[65,66]}$.

The thermal conductivity of the $\mathrm{Mg}$ alloys has been investigated by some researchers. It was found that the thermal diffusivity and thermal conductivity of $\mathrm{Mg}$ alloys were sensitive to the microstructure and closely related with the atomic sizes of solute atoms ${ }^{[65-67]}$. The addition of alloying element (Al, Sc, Re etc.) reduced the thermal conductivity, while the addition of $\mathrm{Zn}$ to $\mathrm{Mg}$ matrix had smaller effects on the thermal conductivity ${ }^{[67-69]}$. The thermal conductivity of ZM51 alloy at room temperature was measured to be 125 $\mathrm{W} / \mathrm{m} \cdot \mathrm{K}$, almost twice higher than that of $\mathrm{Mg}-\mathrm{Al}$ series and $\mathrm{Mg}-\mathrm{Re}$ series ${ }^{[70]}$. In addition, grain refinement could be considered as a meaningful approach to obtain high thermal conductivity. Equal channel angular extrusion, accumulative roll bonding and back extrusion were employed to refine microstructure, but these procedures are too complicated and far from the application in mass production. The current research work on thermal conductivity of $\mathrm{Mg}$ alloy is still at the preliminary stage, and there is no systematic theory to guide the design of Mg alloys. According to the Wiedemann-Franzlaw model, electrical conductivity is linearly proportional with thermal conductivity. Hucheng Pan et al. tried to find a function between the electrical conductivity and thermal conductivity $^{[71,72]}$. The experimental results showed the electrical resistivity for both $\mathrm{Mg}-\mathrm{Al}$ and $\mathrm{Mg}-\mathrm{Zn}$ alloys varied linearly with composition, but the thermal conductivity did not show such a case.

\section{Summary}

1) The Mg alloy hydrides are still far from meeting the need for commercial applications. Efforts are required to design new alloys and to find efficient preparation methods.

2) There have been dramatic increases in both power and energy density of secondary batteries at the lab scale. However, 
the current electrolyte composition of Mg-ion battery is complicated, and the cost for preparing the magnesium electrode is high. Magnesium ion batteries with simple production process and low cost are quite necessary to be developed.

3) The properties of $\mathrm{Mg}$ alloys for biomedical applications in simulated body fluids should be improved unceasingly. The time for dissolution of the alloys in simulated body environments is still short. Surface modification and new alloy design should be carried out to slow the corrosion speed.

4) The previous researches on $\mathrm{Mg}$ alloys as damping materials, electromagnetic shielding materials and thermal conductive materials are insufficient and lack of systematicness. The accurate and prevalent theories should be concluded to guide the actual research activities.

\section{References}

1 Mordike B L, Ebert T. Materials Science and Engineering A[J], 2001, 302: 37

2 Elke Hombergsmeier. Light Metal Age[J], 2009, 67: 34

3 Andrej Atrens, Song G L, Cao F Y et al. Journal of Magnesium and Alloys[J], 2013, 1: 177

4 Mueller Wolf-Dieter, Nascimento M Lucia, Monica Fernández Lorenzo de Mele. Acta Biomaterialia[J], 2010, 6: 1749

5 Huot J, Ravnsbæk D B, Zhang J et al. Progress in Materials Science [J], 2013, 58: 30

6 Zou J X, Zeng X Q, Ying Y J et al. International Journal of Hydrogen Energy[J], 2013, 38: 2337

7 Eigen N, Keller C, Dornheim M et al. Scripta Materialia[J], 2007, 56: 847

8 Wagemans R W P, Lenth J H V, Jongh P E de et al. Journal of the American Chemical Society[J], 2005, 127: 16675

9 Jia Y, Guo Y N, Zou J et al. International Journal of Hydrogen Energy[J], 2012, 37: 7579

10 Shao H Y, Matsuda J, Li H W et al. International Journal of Hydrogen Energy[J], 2013, 38: 7070

11 Long S, Zou J X, Liu Y N et al. Journal of Alloys and Compounds[J], 2013, 580: 167

12 Norberg N S, Arthur T S, Fredrick S J et al. Journal of the American Chemical Society[J], 2011, 133: 10679

$13 \mathrm{Qu} \mathrm{H}, \mathrm{Du} \mathrm{J}, \mathrm{Pu} \mathrm{C}$ et al. International Journal of Hydrogen Energy[J], 2015, 40: 2729

14 Zheng J Y, Liu X X, Xu P et al. International Journal of Hydrogen Energy[J], 2012, 37: 1048

15 Luo F P, Wang H, Ouyang L Z et al. International Journal of Hydrogen Energy[J], 2013, 38: 10912

16 Pelletier J F, Huot J, Sutton M et al. Physical Review B[J], 2001, 63: 2103

17 Friedrichs O, Aguey-Zinsou F, Ares Fernandez J R et al. Acta Materialia[J], 2006, 54: 105

18 Tan X H, Wang L, Holt C M B et al. Physical Chemistry Chemiscal Physics[J], 2012, 14: 10904

19 Braun P V, Cho J, Pikul J H et al. Current Opinion in Solid State and Materials Science[J], 2012, 16: 186

20 Zhao X Y, Ren S H, Bruns M et al. Journal of Power Sources[J], 2014, 245: 706

21 Kakibe T, Hishii J, Yoshimoto $\mathrm{N}$ et al. Journal of Power Sources[J], 2012, 203: 195

22 Zheng Y P, NuLi Y N, Chen Q et al. Electrochimica Acta[J], 2012, 66: 75

$23 \mathrm{Wu} \mathrm{C}$, Bai Y, Wu F et al. Electrochemistry Communications[J], 2009, 11: 2173

24 Tarascon J M, Armand M. Nature[J], 2008, 451: 652

25 Dunn B, Kamath H, Tarascon J M. Science[J], 2011, 334: 928

26 Venkata Narayanan N S, Ashok Raj B V, Sampath S. Electrochemistry Communications[J], 2009, 11: 2027

27 Guo Y G, Hu J S, Wan L J. Advanced Materials[J], 2008, 20: 2878

28 Zhao Q S, NuLi Y N, Guo Y S et al. Progress in Chemistry[J], 2011, 23: 1598

29 NuLi Y N, Yang J, Li Y S et al. Chemical Communications[J], 2010, 46: 3794

30 Xiong H M, Xu Y, Ren Q G et al. Journal of the American Chemical Society[J], 2008, 130: 7522

31 Zhu J J, Guo Y S, Yang J et al. Journal of Power Sources [J], 2014, 248: 690

32 Yan B S, Dong X P, Ma R et al. Materials Science \& Engineering $A[\mathrm{~J}], 2014,594: 168$

33 Liao L H, Zhang X Q, Li X F et al. Materials Letters[J], 2007, 61: 231

$34 \mathrm{Hu}$ X S, Zhang Y K, Zheng M Y et al. Scripta Materialia[J], 2005, 52: 1141

35 Wang J F, Gao S, Pan F S et al. Rare Metal Materials and Engineering[J], 2009, 38(6): 1029 (in Chinese)

36 Wang J F, Lu R P, Qin D Z et al. Materials Science \& Engineering $A[\mathrm{~J}], 2013,562: 667$

37 Hazeli K, Sadeghi A, Pekguleryuz M O et al. Materials Science \& Engineering $A[\mathrm{~J}], 2014,589: 275$

38 Nishiyama K, Matsui R, Ikeda Y et al. Journal of Alloys and Compounds[J], 2003, 355: 22

39 Somekawa H, Watanabe H, Mukai T. Materials Letters[J], 2011, 65: 3251

40 Zheng M Y, Fan G D, Tong L B et al. Transactions of Nonferrous Metals Society of China[J], 2008, 18(1): 33

41 Wang J F, Lu R P, Wei W W et al. Journal of Alloys and Compounds[J], 2012, 537: 1

42 Ma R, Dong X P, Yan B S et al. Materials Science \& Engineering $A[\mathrm{~J}], 2014,602: 11$

43 Ma R, Dong X P, Chen S Q et al. Materials Science \& Engineering $A[\mathrm{~J}], 2013,587: 328$

44 Tan L L, Yu X M, Wan P et al. Journal of Materials Science and Technology[J], 2013, 29: 503

45 Moravej M, Purnama A, Fiset M et al. Acta Biomaterialia[J], 2010, 6: 1843

46 Wang J, He Y, Maitz M F et al. Acta Biomaterialia[J], 2013, 9: 8678 
47 Wu G S, Ibrahim J M, Chu P K. Surface \& Coatings Technology [J], 2013, 233: 2

48 Cui W, Beniash E, Gawalt E et al. Acta Biomaterialia[J], 2013, 9: 8650

49 Razavia M, Fathi M, Savabi O et al. Ceramics International[J], 2014, 40: 3865

50 Rojaee R, Fathi M, Raeissi K et al. Ceramics International[J], 2014, 40: 7879

51 Sankara Narayanan T S N, Song Park 1 1, Lee Min Ho. Progress in Materials Science [J], 2014, 60: 1

52 Gu X N, Li N, Zhou W R et al. Acta Biomaterialia[J], 2011, 7: 1880

53 llich J Z, Kerstetter J E. Journal of the American College of Nutrition[J], 2000, 19: 715

54 Tapiero H, Tew K D. Biomedicine and Pharmacotherapy[J], 2003, 57: 399

55 Gu X N, Xie X H, Li N et al. Acta Biomaterialia[J], 2012, 8: 2360

56 Bornapour M, Celikin M, Cerruti M et al. Materials Science \& Engineering $C[\mathrm{~J}], 2014,35: 267$

57 Saini P, Choudhary V. Journal of Materials Science[J], 2013, 48: 797

58 Al-Shabib W, Habibi D, Xie Z H et al. Proceedings of the 2012 Asia-Pacific Electromagnetic Compatibility (APEMC)[C]. Singapore: IEEE, 2012: 741

59 Chen Z P, Xu C, Ma C Q et al. Advanced Materials[J], 2013, 25:
1296

60 Al-Saleh M H, Saadeh W H, Sundararaj U. Carbon[J], 2013, 60: 146

61 Gupta T K, Singh B P, Teotia Saish et al. Journal of Nanoparticle Research[J], 2011, 13: 7065

62 Zhang Z H, Pan F S, Chen X H et al. Material Engineering[J], 2013, 1: 52

63 Chen X H, Liu J, Zhang Z H et al. Materials and Design[J], 2012, 42: 327

64 Chen X H, Liu J, Pan F S. Journal of Physics and Chemistry of Solids[J], 2013, 74: 872

65 Yamasaki M, Kawamura Y. Scripta Materialia[J], 2009, 60: 264

66 Chen C J, Wang Q D, Yin D D. Journal of Alloys and Compounds[J], 2009, 487: 560

67 Rudajevova A, Stane`k M, Lukác $`$ P. Materials Science \& Engineering $A[\mathrm{~J}], 2003,341: 152$

68 RudajevováA, Von Buch F, Mordike B. Journal of Alloys and Compounds[J], 1999, 292: 27

69 Yuan J W, Zhang K, Li T et al. Materials and Design[J], 2012, 40: 257

70 Yuan J W, Zhang K, Zhang X H et al. Journal of Alloys and Compounds[J], 2013, 578: 32

71 Pan H C, Pan F S, Peng J et al. Journal of Alloys and Compounds[J], 2013, 578: 493

72 Pan H C, Pan F S, Wang X et al. Int Journals of Thermophysics [J], 2013, 34: 1336

\title{
镁合金功能材料的研究进展
}

\author{
陈先华 ${ }^{1,2}$, 耿玉晓 ${ }^{1}$, 潘复生 ${ }^{2,3}$ \\ (1. 重庆大学, 重庆 400045)
}

(2. 国家镁合金材料工程技术研究中心，重庆 400045)

(3. 重庆市科学技术研究院, 重庆 401123)

\begin{abstract}
摘 要: 与其它结构金属材料相比, 镁合金具有质轻的显著优点, 因此被广泛应用于交通运输和航空等领域。随着研究的深入和研究范 围的扩大, 镁合金更多的优点被开发利用: 较高的理论能量密度, 较大的阻尼容量和屏蔽效能以及良好的生物相容性。因此镁合金具有 作为储氢材料、可再充电电池、阻尼材料、可生物降解的植入材料、电磁屏蔽材料、导热材料的潜力, 但是每一种功能材料都存在未解 决的瓶颈问题。本文针对近年来大量的研究工作进行了概括, 总结了镁及镁合金作为以上 6 种功能材料的主要研究方向及研究进展, 讨 论了未来主要的研究方向。
\end{abstract}

关键词：镁合金; 功能材料; 新工艺; 性能; 合金化

作者简介: 陈先华, 男, 1978 年生, 博士, 教授, 重庆大学, 重庆 400045, 电话: 023-65102633, E-mail: xhchen@cqu.edu.cn 